\begin{tabular}{|c|c|}
\hline & $\begin{array}{l}\text { International Journal of Trend in Scientific } \\
\text { Research and Development (IJTSRD) }\end{array}$ \\
\hline 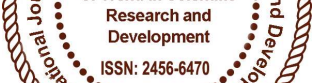 & International Open Access Journal \\
\hline 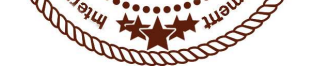 & ISSN No: 2456 - 6470 | www.ijtsrd.com | Volume - 2 | Issue - 2 \\
\hline
\end{tabular}

\title{
Analysis and Control of Grid Connected DFIG Under Sub \& Super Synchronous Modes of Operation
}

\author{
T. Suhasini \\ Guide \& Assistant Professor, EEE Department \\ Amrita Sai Institute of Science \& Technology, \\ Paritala, Andhra Pradesh, India
}

\author{
M. Mohana Rekha \\ M.Tech Scholar, EEE Department \\ Amrita Sai Institute of Science \& Technology, \\ Paritala, Andhra Pradesh, India
}

\section{ABSTRACT}

The most reliable system in the present scenario for effective use of the wind power is grid integrated Doubly Fed Induction Generator (DFIG). The implementation of a simple power converter arrangement in the rotor circuit for variable speeds has been proposed. Depending on wind speed, a DFIG based variable speed wind turbine is capable of operating in sub-synchronous or super-synchronous mode of operation using power electronic converters. The power flow in the rotor circuit is controlled for controlling the stator power in both the modes of operation by effecting rotor voltage through IGBT in sub-synchronous mode whereas in super-synchronous mode it is controlled by current sequence through LCI. The complete system has been modeled Using MATLAB/SIMULINK blocks and simulation study has been conducted, the operation of the proposed scheme is illustrated at different operating conditions i.e. above and below synchronous speeds.

Keywords: Line Commutated Inverter (LCI), DFIG, power smoothing, Sinusoidal PWM Inverter.

\section{INTRODUCTION}

The influence of renewable based distributed generation has been increasing intensely into the power system for last two decades [1]. A variable speed generator based wind turbine can extract more power from the wind than a fixed speed wind turbine [2]. Doubly fed induction generator (DFIG) is a popular choice for variable speed wind turbine application, as it is able to generate power at constant voltage and frequency while the rotor speed varies. A decoupled control of the real and reactive power is possible [3-4].In standalone induction generator, both the terminal voltage and frequency will vary with variation in wind speed and load and an excitation capacitor will be required. Whereas in grid connected induction generator, control of the terminal voltage and frequency under change in load and wind speed, is possible and reactive power can be supplied by the grid. The DFIG based Variable-speed wind turbines, will increase the energy output, improves the power quality and reduce mechanical stress on the wind turbine [5]. The direction of the power flow in the rotor circuit depends on the variation of the wind speed. Both the direction and magnitude of the power flow of the machine can be controlled by the power electronic converters. The control dynamics of a DFIG based variable speed wind turbine in two modes of operation and during transition period has been presented in [6]. The authors in [7] presented a simple and easy to implement configuration of DFIG in super synchronous mode with MPPT and power smoothing for wind driven applications.

In exiting literature most of the published papers on the application of DFIG for wind energy conversion systems used force commutated inverters in the rotor circuit and d-q axis control to maintain constant stator power. The proposed works presents another approach which is the power flow approach and a very simple control technique by using line 
commutated SCR inverter in the rotor circuit of the DFIG to explore how to obtain constant power for variable wind speeds. The inter relations among the rotor power (slip power $\mathrm{sP}_{\mathrm{s}}$ ), the air gap power $\mathrm{P}_{\mathrm{s}}$ and the mechanical power $\mathrm{P}_{\mathrm{m}}$ are used to analyze the DFIG based wind energy conversion system.

The rest of the proposed work is ordered as below. Section describes II Power flow in DFIG wind energy conversion system and steady state model of DFIG. In section III the operation of the open and closed loop systems of the proposed scheme employing subsynchronous and super-synchronous modes by using power electronic converters for the grid interface has been analyzed. Section IV presents the development of simulation models of the proposed scheme along with simulation results. In section $\mathrm{V}$ final main observations are concluded.

\section{POWER FLOW \& STEADY STATE MODEL OF DFIG}

\section{A. Power flow in DFIG}

DFIG can be operated in two modes of operation namely; sub-synchronous and super-synchronous modes of operation based on the synchronous speed of the rotor. The power flowing in the rotor of a doubly fed induction machine (i.e. of the wound rotor type) has three components. These are a) the electromagnetic power fetching between the stator and the rotor by the air gap which is named as the air gap power $\mathrm{P}_{\mathrm{s}}$; b) the mechanical power $\mathrm{P}_{\mathrm{m}}$ fetching between the rotor and shaft; c) the slip power $\mathrm{P}_{\mathrm{r}}$ fetching between the rotor and any external source or load (e.g. a converter) through the rotor slip-rings. These three components of rotor power are interrelated, under sub and supersynchronous modes of operation, as shown in figure. 1

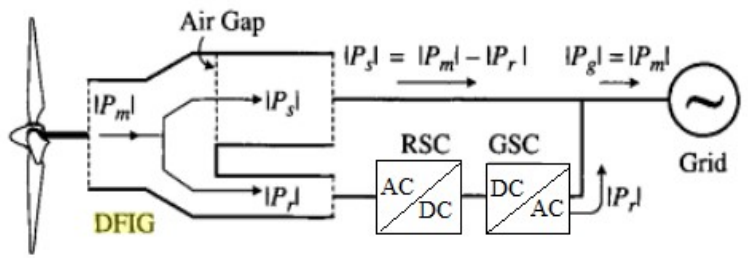

(a) Supersynchronous mode

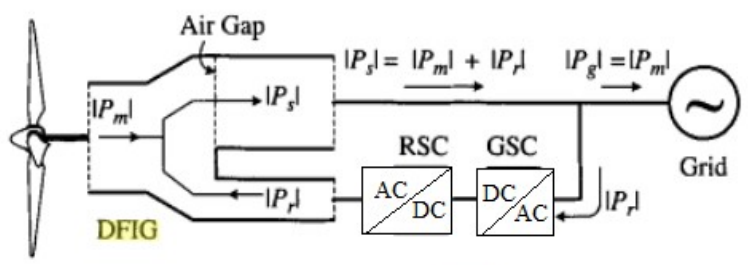

(b) Subsynchronous mode

Fig.1. Power flow in DFIG wind energy conversion system

\section{B. Steady State Model}

The typical steady-state per-phase equivalent circuit can be utilized to assess the performance of doubly fed induction machine subject to the usual assumptions of a three-phase balanced supply, fixed rotor speed, and constant machine parameters. Fig. 2 shows the standard per-phase equivalent circuit of DFIG in which stator frequency is used to refer the rotor circuit parameters, so at the supply frequency all machine reactance's are determined.

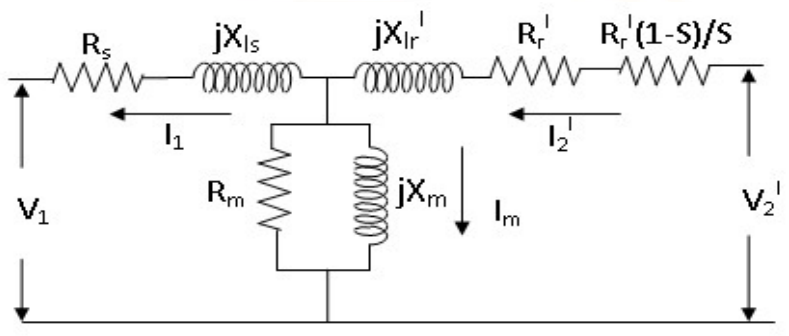

Fig.2. Per-phase equivalent circuit of a DFIG

The per unit power into the rotor circuit comes from two sources when machine is doubly-fed and

$$
\begin{aligned}
& \mathrm{P}_{\mathrm{r}, \text { in } 1}=\operatorname{Re}\left(\left[\mathrm{V}_{2}^{\prime}\left(\mathrm{I}_{2}^{\prime}\right)^{*}\right]\right) \\
& \mathrm{P}_{\mathrm{r}, \text { in } 2}=\mathrm{T}\left(\omega_{\mathrm{r}} / \omega_{\mathrm{b}}\right)=\mathrm{T}(1-\mathrm{S})
\end{aligned}
$$

Where $(*)$ denotes the complex conjugate operator. Since the machine is a generator, positive ' $\mathrm{T}$ 'denotes the operation of the generator.

The power lost in the rotor circuit is

$$
\mathrm{P}_{\mathrm{r}, \mathrm{loss}}=\left|\mathrm{I}_{2}\right|^{2} \mathrm{R}_{\mathrm{r}}{ }^{\prime}
$$

The power output of the circuit is

$\mathrm{P}_{\mathrm{r}, \text { out }}=\operatorname{Re}\left[\mathrm{E}\left(\mathrm{I}_{2}\right)^{*}\right]$

Conservation of power requires that

$\mathrm{P}_{\mathrm{r}, \text { in } 1}+\mathrm{P}_{\mathrm{r}, \text { in } 2}=\mathrm{P}_{\mathrm{r}, \text { loss }}+\mathrm{P}_{\mathrm{r} \text {, out }}$

So that

$$
\begin{aligned}
& \operatorname{Re}\left[\mathrm{V}_{2}^{\prime}\left(\mathrm{I}_{2}\right)^{*}\right]+\mathrm{T}(1-\mathrm{S})=\operatorname{Re}\left[\mathrm{E}\left(\mathrm{I}_{2}\right)^{*}\right]+\left|\mathrm{I}_{\mathrm{s}}\right|^{2} \mathrm{R}_{\mathrm{r}}{ }^{\prime} \\
& \text { Or } \\
& \mathrm{T}(1-\mathrm{S})=\operatorname{Re}\left[\mathrm{E}\left(\mathrm{I}_{2}\right)^{*}\right]-\operatorname{Re}\left[\mathrm{V}_{2}{ }^{\prime}\left(\mathrm{I}_{2}{ }^{\prime}\right)^{*}\right]+\left|\mathrm{I}_{\mathrm{s}}\right|^{2} \mathrm{R}_{\mathrm{r}}{ }^{\prime}
\end{aligned}
$$

But

$$
\bar{E}=\frac{V_{2}^{\prime}}{S}-\mathrm{I}_{2}{ }^{\prime}\left[\frac{\mathrm{R}_{\mathrm{r}}^{\prime}}{\mathrm{s}}+\mathrm{j} \mathrm{X}_{\mathrm{lr}}{ }^{\prime}\right]
$$


Eq. (8) is substituting into Eq. (7),

$$
\mathrm{T}(1-\mathrm{S})=\operatorname{Re}\left[\left(\frac{1}{s}-1\right) \mathrm{V}_{2}^{\prime}\left(\mathrm{I}_{2}^{\prime}\right)\right]+\left|\mathrm{I}_{2}^{\prime}\right|^{2} \mathrm{R}_{\mathrm{r}}^{\prime}\left(1-\frac{1}{s}\right)
$$

Or

$$
\mathrm{T}(1-\mathrm{S})=\operatorname{Re}\left[\left(\frac{1-s}{s}\right) \mathrm{V}_{2}{ }^{\prime}\left(\mathrm{I}_{2}\right)^{*}\right]^{*}\left|\mathrm{I}_{2}\right|^{2} \mathrm{R}_{\mathrm{r}}^{\prime}\left(\frac{1-s}{s}\right)
$$

Cancelling out the (1-s) term

$$
\mathrm{T}=\operatorname{Re}\left[\frac{V_{2}^{\prime}}{S}\left(\mathrm{I}_{2}{ }^{\prime}\right)^{*}\right]--\left|\mathrm{I}_{2}{ }^{\prime}\right|^{2} \frac{\mathrm{R}_{\mathrm{r}}^{\prime}}{\mathrm{s}}
$$

This final equation represents the basic torque equation for a doubly fed induction generator.

Solution of eq.11 in terms of the rotor current has been developed by Smith et. al [8]. Expanding eq. $(11)$,

$\left.\mathrm{T}=\frac{V_{2, r e}^{\prime}}{s} \mathrm{I}_{2, \text { re }}{ }^{\prime}+\frac{V_{2, i m}^{\prime}}{s} \mathrm{I}_{2, \text { im }}{ }^{\prime}-\left(\mathrm{I}_{2,}{ }^{\prime}\right)^{2}\right)^{2} \frac{\mathrm{R}_{\mathrm{r}}^{\prime}}{\mathrm{s}}-\left(\mathrm{I}_{2, \mathrm{im}}\right)^{2} \frac{\mathrm{R}_{\mathrm{r}}^{\prime}}{\mathrm{s}}$

The phase position of the rotor voltage is generally defined as its relative phase position with respect to the stator terminal voltage $V_{1}$. Hence, $V_{2, r e}^{\prime}$ and $V_{2, i m}^{\prime}$ can be assumed to be known or specified quantities. Assuming that $T$ and $\mathrm{S}$ are also specified, then the currents can be obtained by solving Eq. (12) by also assuming that their ratio (power factor) is specified. Other method, is instead of assuming rotor voltage is known assume the phase position of the rotor current is known to solve the eq. 12. In this case, assuming the real part of the stator current as reference,

$$
\mathrm{I}_{2, \text { im }}{ }^{\prime}=0
$$

And

$$
\mathrm{I}_{2, \mathrm{re}}{ }^{\prime}=\mathrm{I}_{2}{ }^{\prime}
$$

Eq. (12) becomes

$$
\mathrm{T}=\frac{V_{2, r e}^{\prime}}{s} \mathrm{I}_{2}^{\prime}-\left(\mathrm{I}_{2}^{\prime}\right)^{2} \frac{\mathrm{R}_{\mathrm{r}}^{\prime}}{\mathrm{s}}
$$

Which is simply a quadratic in terms of $\mathrm{I}_{2}{ }^{\prime}$.Upon solving eq.(15).

$$
\mathrm{I}_{2}{ }^{\prime}=\frac{\frac{V_{2, r e}^{\prime}}{s} \pm \sqrt{\left(\frac{v_{2, r e}^{\prime}}{s}\right)^{2}-4 \frac{\mathrm{R}_{\mathrm{r}}^{\prime}}{\mathrm{s}} \mathrm{T}}}{2 \frac{\mathrm{R}_{\mathrm{r}}^{\prime}}{\mathrm{s}}}
$$

Or

$$
\mathrm{I}_{2}{ }^{\prime}=\frac{V_{2, r e}^{\prime}}{2 \mathrm{R}_{\mathrm{r}}^{\prime}} \pm \frac{\sqrt{\left(V_{2, r e}^{\prime}\right)^{2}-4 \mathrm{R}_{\mathrm{r}}^{\prime} \mathrm{sT}}}{2 \mathrm{R}_{\mathrm{r}}^{\prime}}
$$

The voltage $V_{2, r e}^{\prime}$ can also be written as $V_{2}^{\prime} \cos \Phi_{2}$ where $\Phi 2$ represents the phase angle of the rotor terminal voltage $\mathrm{V}_{2}^{\prime}$ with respect to the rotor input current $\mathrm{I}_{2}{ }^{\prime}$. Now the rotor current $\mathrm{I}_{2}{ }^{\prime}$ can be obtained as a function of slip for any desired torque and specified value of rotor voltage and phase.

By obtaining the rotor current from eq. (17) now it is possible to obtain the air gap voltage $E$ from eq. (8).

Then the stator current can be found from,

$$
\mathrm{I}_{1}=\mathrm{I}_{2}^{\prime}-\mathrm{E}\left(\frac{1}{R_{m}}+\frac{1}{j X_{m}}\right)
$$

The stator voltage can be obtained by the stator loop equation

$$
\mathrm{V}_{1}=\mathrm{E}-\mathrm{I}_{1}\left(\mathrm{R}_{\mathrm{s}}+\mathrm{j} \mathrm{X}_{\mathrm{ls}}\right)
$$

In general, the voltage obtained will not be same as the available terminal voltage except at specific combinations of rotor voltage and slip. Hence, emphasis is necessary to converge on the correct values which correspond to the specified stator terminal voltage.

\section{OPERATION UNDER SUB AND SUPER SYNCHRONOUS MODES}

Depending on wind speed, using power electronic converters a doubly fed induction generator (DFIG) based variable speed wind turbine can be operated in sub-synchronous or super-synchronous modes of operation. Traditional Wound Rotor Induction Generator (WRIG) will never obtain power at subsynchronous mode of operation. In this mode, it generates motoring torque which can be used to control rotor voltage or current. Rotor side converter component must need to be controlled properly for proper operation of the machine under subsynchronous and super-synchronous modes. The imposed voltage and current for the rotor circuit of the machine can be controlled by the rotor side converter. The control of imposed current is necessary for generating torque in sub-synchronous mode of operation. Whereas the control of voltage or current is necessary to utilize extra generating torque in supersynchronous mode. 
During sub-synchronous mode, the speed of the rotor is less than the synchronous speed of the machine. As a result, the slip is positive $(\mathrm{s}>0)$, and a motoring torque is produced. To utilize this torque, negative power (according to the positive slip) is required in the rotor circuit of the machine. This can be obtained by changing the rotor circuit injected voltage magnitude and the rotor receives power form the grid through grid side converter and DC-link. In super-synchronous mode, the rotor speed is greater than the synchronous speed of the machine and slip is negative $\quad(s<0)$. To supply extra generating power to the grid through DC-link and grid side converter the rotor voltage/current sequence has to be reversed. The magnitude of the rotor current and voltage will get changed according to the wind variations.

The mechanical power and the stator electric power output are computed as follows:

$$
\begin{aligned}
& P_{r}=T_{m} * \omega_{r} \\
& P_{s}=T_{e m} * \omega_{s}
\end{aligned}
$$

For a loss-less generator, the mechanical equation is:

$J \frac{d \omega_{r}}{d t}=T_{m}-T_{e m}$

In steady-state at fixed speed for a loss-less generator

$T_{m}=T_{e m}$ and $p_{m}=P_{s}+P_{r}$

And it follows that

$$
p_{r}=P_{m}-P_{s}=T_{m} \omega_{r}-T_{e m} \omega_{s}=-s P_{s}
$$

where

$s=\left(\omega_{s}-\omega_{r}\right) / \omega_{s}$

$\mathrm{s}$ is defined as the slip of the generator.

Generally, the absolute value of slip (s) is much lower than 1 and, therefore, $\mathrm{P}_{\mathrm{r}}$ is only a fraction of $P_{s}$. Since $T_{m}$ is positive for power generation and since $\omega_{\mathrm{s}}$ is positive and constant for a constant frequency grid voltage, the sign of $\mathrm{P}_{\mathrm{r}}$ is a function of the slip sign. $\mathrm{P}_{\mathrm{r}}$ is positive for negative slip (speed greater than synchronous speed) and vice-versa (speed lower than synchronous speed). For supersynchronous speed operation, $\mathrm{P}_{\mathrm{r}}$ is transmitted to DC bus capacitor and tends to increase the $\mathrm{DC}$ voltage. For sub-synchronous speed operation, $\mathrm{P}_{\mathrm{r}}$ is taken out of DC bus capacitor and tends to decrease the DC voltage. $\mathrm{PC}_{\text {grid }}$ is used to generate or absorb the power $\mathrm{P}_{\mathrm{g}}$ in order to keep the constant DC voltage as shown in Fig.3. In steady-state for a lossless $\mathrm{AC} / \mathrm{DC} / \mathrm{AC}$ converter $\mathrm{P}_{\mathrm{g}}$ is equal to $\mathrm{P}_{\mathrm{r}}$ and the wind turbine speed is determined by the power $\mathrm{P}_{\mathrm{r}}$ absorbed or generated by $\mathrm{PC}_{\text {rotor }}$. The generated $\mathrm{AC}$ voltage phase-sequence by $\mathrm{PC}_{\text {rotor }}$ is positive for subsynchronous speed and negative for super synchronous speed. The product of the grid frequency and the absolute value of the slip is equal to the frequency of this voltage. $\mathrm{PC}_{\text {rotor }}$ and $\mathrm{PC}_{\text {grid }}$ have the capability for generating or absorbing reactive power and could be used to control the reactive power or the voltage at the grid terminals.

A dc-link capacitor is placed between the two converters, for energy storing, in order to keep the voltage

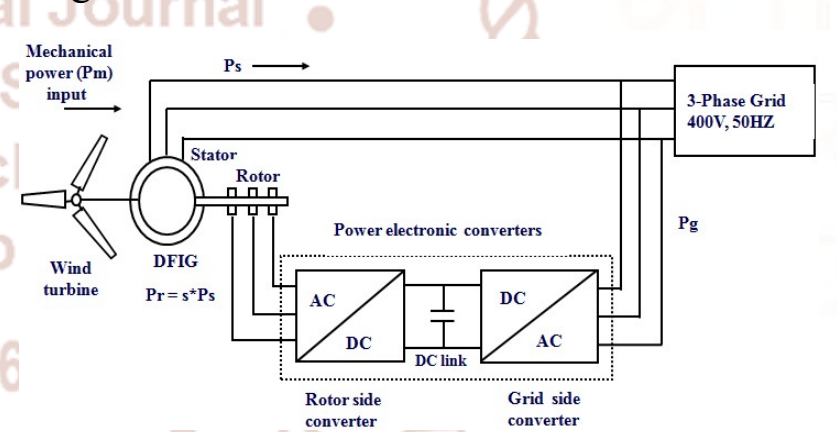

Fig.3. DFIG system with power electronic converters

variations (or ripple) in the dc-link voltage small. It is possible to control the torque or the speed of the DFIG with the machine-side converter and also the power factor at the stator terminals, while the main objective of the grid-side converter is to keep the dclink voltage constant.

\section{SIMULATION STUDIES OF PROPOSED SCHEME}

This section discusses the modeling of DFIG, power electronic converters and the simulation results of the overall scheme in both sub-synchronous and supersynchronous modes of operation.

\section{A. Open Loop Super-Synchronous Mode}

The schematic diagram for open loop supersynchronous mode of operation is shown in Fig.3. 
Ratings of DFIG used in the proposed scheme are: Nominal power $(\mathrm{P})=2.65 \mathrm{~kW}, \mathrm{~V}_{\mathrm{L}-\mathrm{L}}=400 \mathrm{~V}, \mathrm{f}=$ $50 \mathrm{~Hz}$, synchronous speed (Ns) $=1000 \mathrm{rpm}$, number of poles $(\mathrm{P})=6$ [3]. In open loop super-synchronous mode firing angle $\left(\alpha>90^{\circ}\right)$ of the line commutated inverter is varied manually to maintain the constant stator power at $2.65 \mathrm{~kW}$ for speeds varying from $1050 \mathrm{rpm}$ to $1200 \mathrm{rpm}$. As the speed varies, the power delivered to the grid by the rotor is varied but the stator power is maintained constant.
The parameters chosen for the simulation study are:

$\begin{array}{lc}\text { stator resistance } & : 0.8285 \Omega \\ \text { stator leakage inductance } & : 3.579 \mathrm{mH} \\ \text { rotor resistance } & : 0.7027 \Omega \\ \text { rotor leakage inductance } & : 3.579 \mathrm{mH} \\ \text { magnetizing inductance } & : 62.64 \mathrm{mH}\end{array}$

The simulation model for this mode of operation is developed and the simulation results obtained are given in Table 1.

Table.1: Simulation results for open loop super-synchronous mode

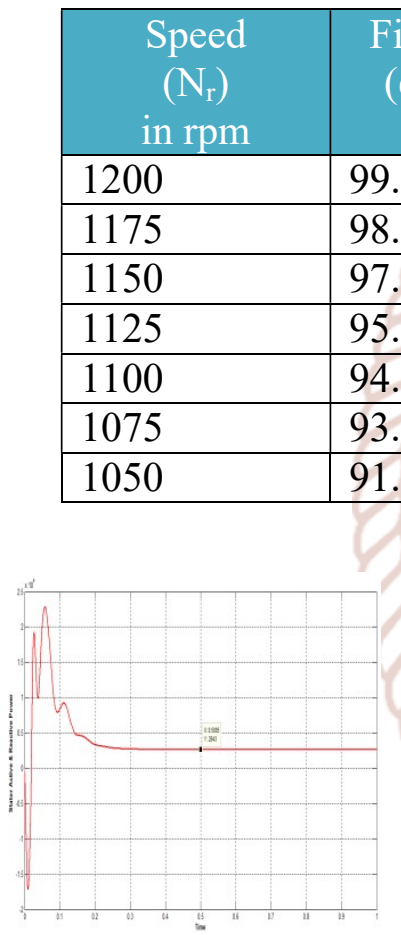

(a) $\mathrm{Nr}=1200 \mathrm{rpm}$

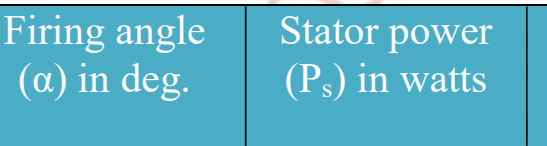

Rotor power

$\left(\mathrm{P}_{\mathrm{r}}\right)$ in watts
Rect.

voltage in volts
LCI current

$\left(\mathrm{I}_{\mathrm{act}}\right)$ in amp

\begin{tabular}{|l|l|l} 
& \multicolumn{1}{|c|}{ in volts } & \\
\hline 548.1 & 93.17 & 5.977 \\
\hline 474.0 & 80.56 & 5.990 \\
\hline 400.3 & 68.23 & 6.005 \\
\hline 323.3 & 55.40 & 5.988 \\
\hline 247.5 & 42.72 & 5.984 \\
\hline 171.3 & 31.23 & 5.899 \\
\hline 93.79 & 17.96 & 5.800 \\
\hline
\end{tabular}

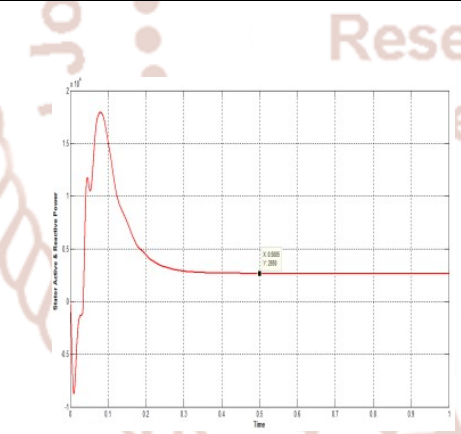

(b) $\mathrm{Nr}=1100 \mathrm{rpm}$

Fig.4. Variation of active power delivered at the stator side

Fig.4. shows the variation of active power of the stator for varying rotor speeds of $1200 \mathrm{rpm}$ and 1100 $\mathrm{rpm}$. It can be seen that the stator power is delivered to the grid and is maintained at around $2.65 \mathrm{~kW}$ for both speeds by controlling the line commutated inverter firing angle.

Similarly, from Fig.5 shows the active power of the rotor delivered to the grid is maintained at slip times the stator power in both speeds i.e., $1200 \mathrm{rpm}$ and $1100 \mathrm{rpm}$ by controlling the line commutated inverter firing angle.

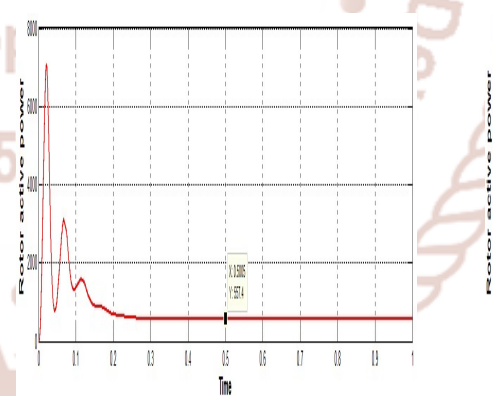

(a) $\mathrm{Nr}=1200 \mathrm{rpm}$

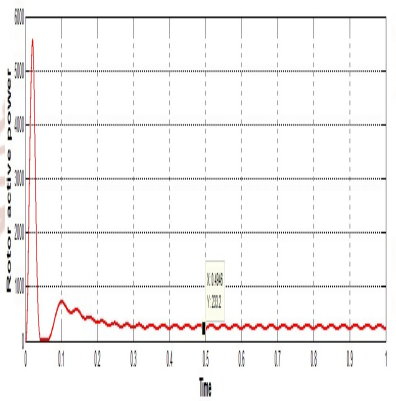

(b) $\mathrm{Nr}=1100 \mathrm{rpm}$
Fig.5. Variation of active power delivered at the rotor side

\section{B. Closed Loop Super-Synchronous Mode}

Fig.6. shows the simulation model of the closed loop super synchronous mode, in which the firing angle $\left(\alpha>90^{\circ}\right)$ of the line commutated inverter is varied automatically i.e., the actual DC link current, $\mathrm{I}_{\mathrm{act}}$ is compared with the reference current, $\mathrm{I}_{\text {ref }}$ and any mismatch is used to change the firing angle $\alpha$, of the inverter as follows $\alpha=\left(\mathrm{I}_{\text {ref }}-\mathrm{I}_{\mathrm{act}}\right) *\left[\mathrm{~K}_{\mathrm{p}}+\mathrm{K}_{\mathrm{I}} / \mathrm{s}\right]$ where $\mathrm{K}_{\mathrm{p}}$ and $\mathrm{K}_{\mathrm{I}}$ are the proportional and integral stage gains respectively. The optimum values for $\mathrm{K}_{\mathrm{p}}$ and $\mathrm{K}_{\mathrm{I}}$ have 
been arrived at by trial and error method [4]. The the $\mathrm{P}$ and $\mathrm{I}$ controller gains $\left(\mathrm{K}_{\mathrm{P}}=0.5\right.$ and $\left.\mathrm{K}_{\mathrm{I}}=100\right)$ range of mechanical torque of the wind turbine is taken into account to choose the values. This range will represent the variation in wind speed with which have been chosen to operate the system with rotor speed varying from $1050 \mathrm{rpm}$ to $1200 \mathrm{rpm}$, to maintain the stator power constant at $2.65 \mathrm{~kW}$. the system has to operate. In this proposed scheme,

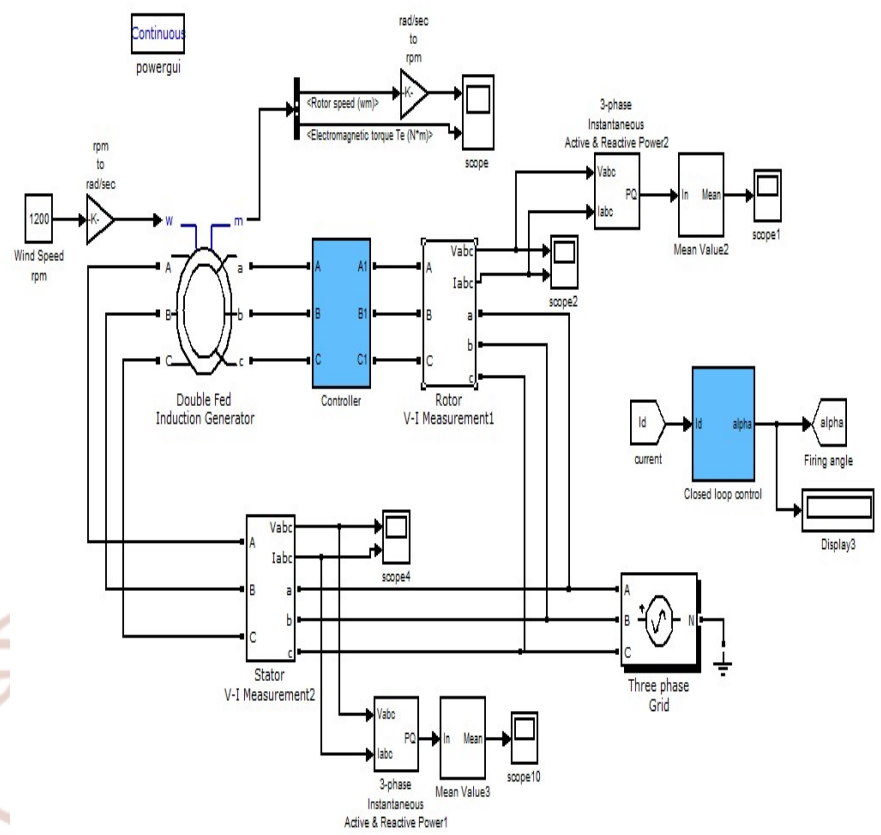

Fig.6. Simulation model of the closed loop super-synchronous mode

Fig.7. shows the variation of active power of the stator for varying rotor speeds of $1200 \mathrm{rpm}$ and $1100 \mathrm{rpm}$. It can be seen that the stator power is delivered to the grid and is maintained at around $2.65 \mathrm{~kW}$ for both speeds by controlling the firing angle of line commutated inverter.

Table.2: Simulation results for closed loop super-synchronous mode

\begin{tabular}{|l|l|l|l|l|l|}
\hline $\begin{array}{c}\text { Speed }\left(\mathrm{N}_{\mathrm{r}}\right) \\
\text { in rpm }\end{array}$ & $\begin{array}{c}\text { Firing angle } \\
(\alpha) \text { in deg. }\end{array}$ & $\begin{array}{c}\text { Stator power } \\
\left(\mathrm{P}_{\mathrm{s}}\right) \text { in watts }\end{array}$ & $\begin{array}{c}\text { Rotor power } \\
\left(\mathrm{P}_{\mathrm{r}}\right) \text { in watts }\end{array}$ & $\begin{array}{c}\text { Rect.voltage } \\
\text { in volts }\end{array}$ & $\begin{array}{l}\text { LCI current } \\
\left(\mathrm{I}_{\text {act }}\right) \text { in amp }\end{array}$ \\
\hline 1200 & 99.87 & 2653 & 550.1 & 93.17 & 6.000 \\
\hline 1175 & 98.52 & 2667 & 474.6 & 80.55 & 5.998 \\
\hline 1150 & 97.18 & 2679 & 399.1 & 68.00 & 5.991 \\
\hline 1125 & 95.83 & 2688 & 324.0 & 55.18 & 6.007 \\
\hline 1100 & 94.49 & 2687 & 249.8 & 42.63 & 6.050 \\
\hline 1075 & 93.14 & 2660 & 176.1 & 30.58 & 6.010 \\
\hline 1050 & 91.83 & 2650 & 99.5 & 17.57 & 6.020 \\
\hline
\end{tabular}

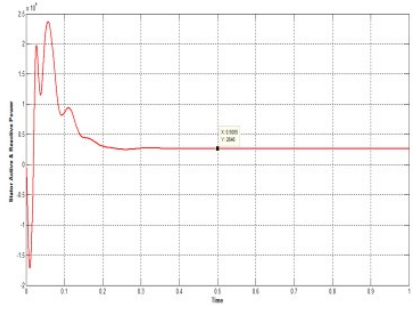

(a) $\mathrm{Nr}=1200 \mathrm{rpm}$

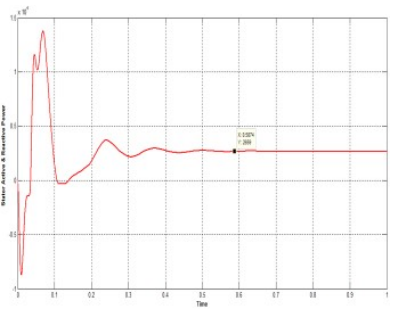

(b) $\mathrm{Nr}=1100 \mathrm{rpm}$
Similarly Fig.8.shows the variation of the active power of the rotor delivered to the grid is maintained at slip times the stator power for both speeds i.e., $1200 \mathrm{rpm}$ and $1100 \mathrm{rpm}$ by controlling the firing angle of line commutated inverter.

Fig.7. Variation of active power delivered at the stator side 


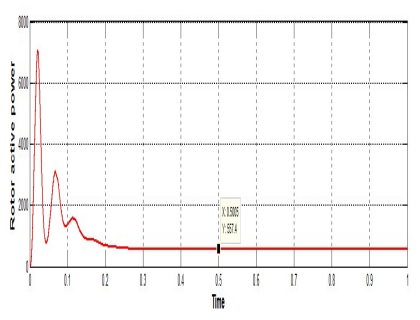

(a) $\mathrm{Nr}=1200 \mathrm{rpm}$

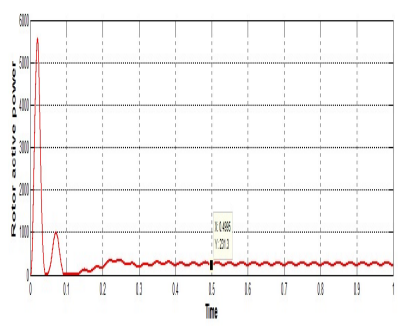

(b) $\mathrm{Nr}=1100 \mathrm{rpm}$
Fig.8. variation of active power delivered at the rotor side

\section{Open Loop Sub-Synchronous Mode}

In open loop sub-synchronous mode, modulation index of the sinusoidal pulse width modulation inverter is varied manually to maintain the stator power constant at $2.65 \mathrm{~kW}$ for speeds varying from $800 \mathrm{rpm}$ to $950 \mathrm{rpm}$. As the speed varies, the rotor power absorbed from the grid is varied but stator power is maintained constant.
The simulation model for this mode of operation is developed and the simulation results obtained are given in Table.3.

Fig.9 shows the variation of active power of the stator for varying rotor speeds of $800 \mathrm{rpm}$ and 900 $\mathrm{rpm}$. It can be seen that the stator power delivered to the grid is maintained at $2.65 \mathrm{~kW}$ for both speeds by controlling the modulation index of the sinusoidal PWM inverter.

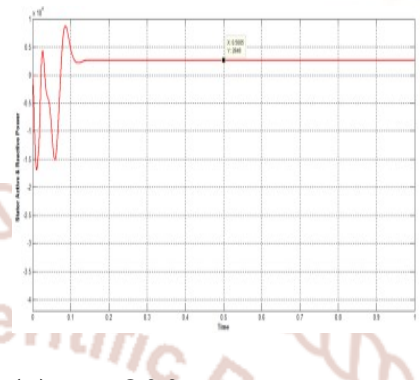
(a) $\mathrm{Nr}=800 \mathrm{rpm}$
(b) $\mathrm{Nr}=900 \mathrm{rpm}$

Fig.9. Variation of active power delivered at the stator side

Table.3: Simulation results for open loop sub-synchronous mode

\begin{tabular}{|c|c|c|c|c|c|}
\hline $\begin{array}{l}\text { Speed } \\
\left(\mathrm{N}_{\mathrm{r}}\right) \\
\text { in rpm }\end{array}$ & $\begin{array}{l}\text { Modula- } \\
\text {-tion } \\
\text { index (m) }\end{array}$ & $\begin{array}{l}\text { Stator power } \\
\left(\mathrm{P}_{\mathrm{s}}\right) \text { in watts }\end{array}$ & $\begin{array}{l}\text { Rotor power } \\
\left(\mathrm{P}_{\mathrm{r}}\right) \text { in watts }\end{array}$ & $\begin{array}{l}\text { Rotor freq } \\
\left(f_{r}\right) \text { in } \mathrm{Hz}\end{array}$ & $\begin{array}{c}\text { Rotor } \\
\text { voltage } \\
\text { (RMS) in } \\
\text { volts }\end{array}$ \\
\hline 800 & $0.2500 \bigcirc$ & $2648 \mathrm{CCN} \cdot 2$ & $651.17 n$ & 10.0 & 85.62 \\
\hline 825 & 0.2195 & $2650 \cup \cup T=2$ & 574.6 & 8.75 & 74.96 \\
\hline 850 & 0.1893 & 2650 & 498.0 & 7.50 & 64.99 \\
\hline 875 & 0.1594 & 2650 & 421.5 & 6.25 & 54.86 \\
\hline 900 & 0.1299 & 2652 & $345.8-1 y$ & 5.00 & 44.73 \\
\hline 925 & 0.1008 & 2655 & 270.1 & 3.75 & 34.79 \\
\hline 950 & 0.0720 & $2647 \times n=$ & 193.6 & 2.50 & 24.88 \\
\hline
\end{tabular}

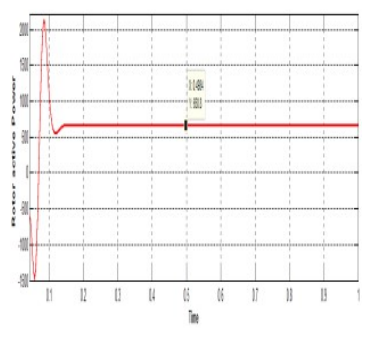

(a) $\mathrm{Nr}=800 \mathrm{rpm}$

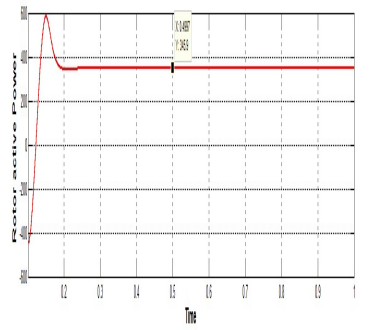

(b) $\mathrm{Nr}=900 \mathrm{rpm}$
Fig.10. Variation of active power absorbed from the grid at the rotor side rotor absorbed from the grid is maintained at slip times the stator power for both speeds i.e., $800 \mathrm{rpm}$ and $900 \mathrm{rpm}$ by controlling the modulation index of the sinusoidal PWM inverter.

\section{Closed Loop Sub-Synchronous Mode}

In closed loop sub-synchronous mode, the modulation index of the sinusoidal pulse width modulation inverter is varied automatically i.e., the actual rotor voltage, $\mathrm{V}_{2}$ is compared with the reference voltage, $\mathrm{V}_{2}$ ref $=\mathrm{s}^{*} \mathrm{~V}_{1}$ and any mismatch is used to change the modulation index $\mathrm{m}$, of the inverter as follows. $\mathrm{m}=\left(\mathrm{V}_{2}-\mathrm{V}_{2}\right.$ ref $) *\left[\mathrm{~K}_{\mathrm{p}}+\mathrm{K}_{\mathrm{I}} / \mathrm{S}\right]$.
Fig.10 shows the variation of active power of the 
The optimum values for $\mathrm{K}_{\mathrm{p}}$ and $\mathrm{K}_{\mathrm{I}}$ have been arrived at by trial and error method. The values have been chosen taking into account the range of mechanical torque of the wind turbine. This range will represent the variation in wind speed with which the system has to operate. In the proposed scheme, the $\mathrm{P}$ and I controller gains $\left(\mathrm{K}_{\mathrm{P}}=0.05\right.$ and $\left.\mathrm{K}_{\mathrm{I}}=2.38\right)$ have been chosen for operating the system with rotor speed varying from $800 \mathrm{rpm}$ to $900 \mathrm{rpm}$, to maintain the stator power constant at $2.65 \mathrm{~kW}$, though the rotor power absorbed from the grid is varied.

The simulation model for this mode of operation is developed and is shown in Fig.11. The simulation results obtained are given in Table. 4

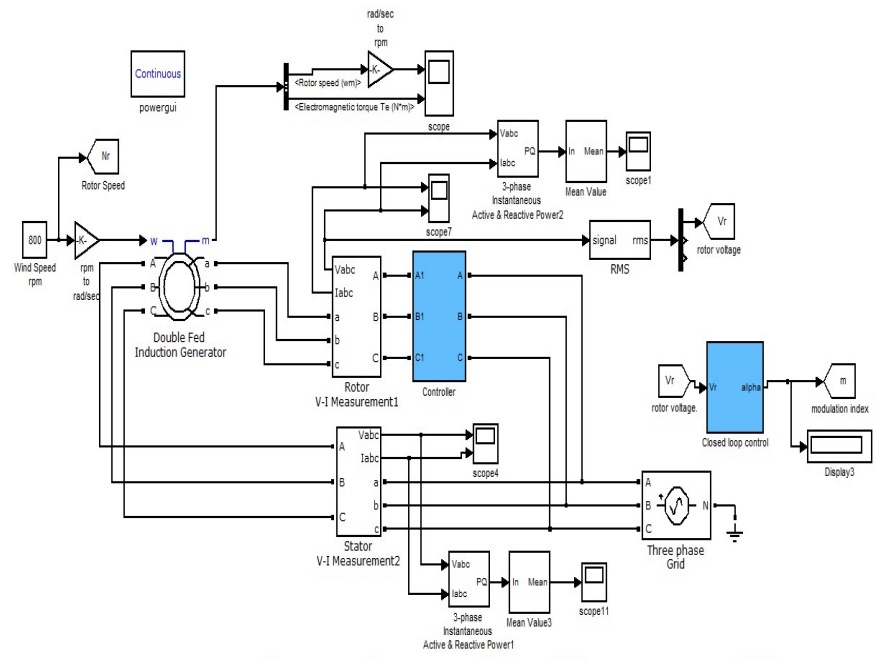

Fig.11. Block diagram for closed loop subsynchronous mode

Table.4: Simulation results for closed loop sub-synchronous mode

\begin{tabular}{|c|c|c|c|c|c|}
\hline $\begin{array}{l}\text { Speed } \\
\left(\mathrm{N}_{\mathrm{r}}\right) \\
\text { in rpm }\end{array}$ & $\begin{array}{l}\text { Modulation } \\
\text { index (m) }\end{array}$ & $\begin{array}{l}\text { Stator power } \\
\left(P_{s}\right) \text { in watts }\end{array}$ & $\begin{array}{l}\text { Rotor power } \\
\left(P_{r}\right) \text { in watts }\end{array}$ & $\begin{array}{l}\text { Rotor freq } \\
\text { (fr) in } \mathrm{Hz}\end{array}$ & $\begin{array}{l}\text { Rotor } \\
\text { voltage in } \\
\text { volts }\end{array}$ \\
\hline 800 & 0.2497 & 2610 & 641.7 & 10.0 & 85.5 \\
\hline 825 & 0.2187 & 2560 & 554.6 & 8.75 & 75.0 \\
\hline 850 & 0.1894 & 2652 irend in & 498.5 entific & $7.50=$ & 64.9 \\
\hline 875 & 0.1603 & 2748 & 437.7 & 6.25 & 55.0 \\
\hline 900 & 0.1320 & 2690 & 318.0 & 5.00 & 44.7 \\
\hline
\end{tabular}

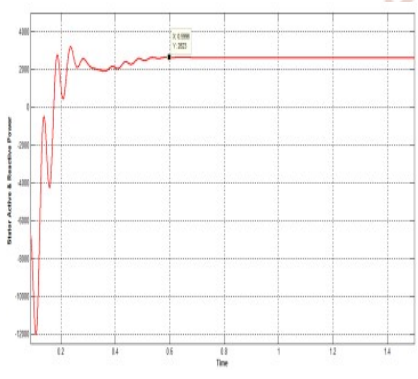

(a) Delivered to the grid

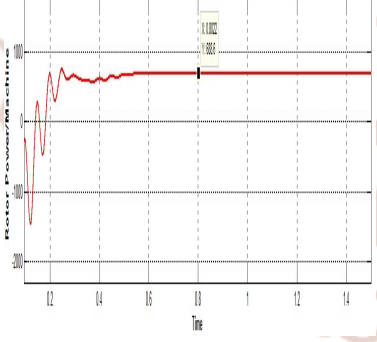

(b) Absorbed from the grid
Fig.12. Variation of active power for $\mathrm{N}_{\mathrm{r}}=800 \mathrm{rpm}$

Fig.12.(a) shows the variation of active power of the stator for speed of $800 \mathrm{rpm}$. It can be seen that the stator power is delivered to the grid and is maintained at $2.65 \mathrm{~kW}$ by controlling the modulation index of the sinusoidal PWM inverter. Similarly Fig.12.(b) shows the variation in active power of the rotor absorbed from the grid is maintained at slip times the stator power.

\section{CONCLUSION}

A very simple and easy to implement configuration of DFIG for wind driven applications in both sub \& super-synchronous modes of operation has been presented. The simulation results in power smoothing mode for variable wind speeds are presented. The analysis of the DFIG in feeding the required power to the grid with the variation in rotor speed is carried out. The simulation results represent the smooth control of active power fed to the grid with variation in rotor speed of the DFIG. Such a system permits to use the wind power in different operating conditions i.e. above and below synchronous speeds that leading to the higher power harvest and therefore higher efficiency of wind energy conversion system. 


\section{REFERENCES}

1) A. Miller, E. Muljadi, and D. Zinger, "A Variable Speed Wind Turbine Power Control”, IEEE Trans. on Energy Conversion, Vol. 12, No. 2, June 1997, pp. 181-186.

2) S. Müller, M. Deicke, and R. W. De Doncker, "Doubly fed induction generator system for wind turbines", IEEE Industry Applications Magazine, pp. 26-33, May/June, 2002.

3) D. J. Atkinson, R. A. Lakin, and R. Jones, "A vector-controlled doubly-fed induction generator for a variable-speed wind turbine application," Trans. Inst. Meas. Contr., vol. 19, no. 1, 1997, pp. 2-12.

4) R. Peña, J. C. Clare, and G. M. Asher, "Doubly Fed Induction Generator using back-to-back PWM converters and its application to variable speed wind-energy generation," Proc. Inst. Elect. Eng., Elect. Power Appl., vol.143, no. 3, pp. 231241, May 1996.

5) T.A.Lipo University of Wisconsin Madison WI USA, "A Super synchronous Doubly Fed
Induction Generator Option for Wind Turbine Applications" IEEE Conference proceedings, 2426 June 2009, pages 1-5.

6) M. Aktarujjaman, M.. E.Haque, K. M.Muttaqi, M. Negnevitsky, and G.Ledwich, sch.of.Eng., Univ.of Tasmania, Hobart, TAS, "Control Dynamics of a Doubly Fed Induction Generator Under Sub and Super-Synchronous Modes of Operation" IEEE Conference Proceedings, 20-24 July 2008, pages 1-9

7) D. R. Binu Ben Jose, N. Ammasai Gounden and R. Sri Naga Ramesh "A unified power electronic controller for wind driven grid connected wound rotor induction generator using line commutated inverter" Frontiers in Energy March 2013, Volume-7, Issue-1, pp.39-48.

8) A.C. Smith, R. Todd, M. Barnes and P.J. Tavner, "Improved Energy Conversion for Doubly Fed Wind Generators", IEEE Trans. on Ind. Applications, Vol. 42, No.6, Nov./Dec. 2006, pp. 1421-1428.

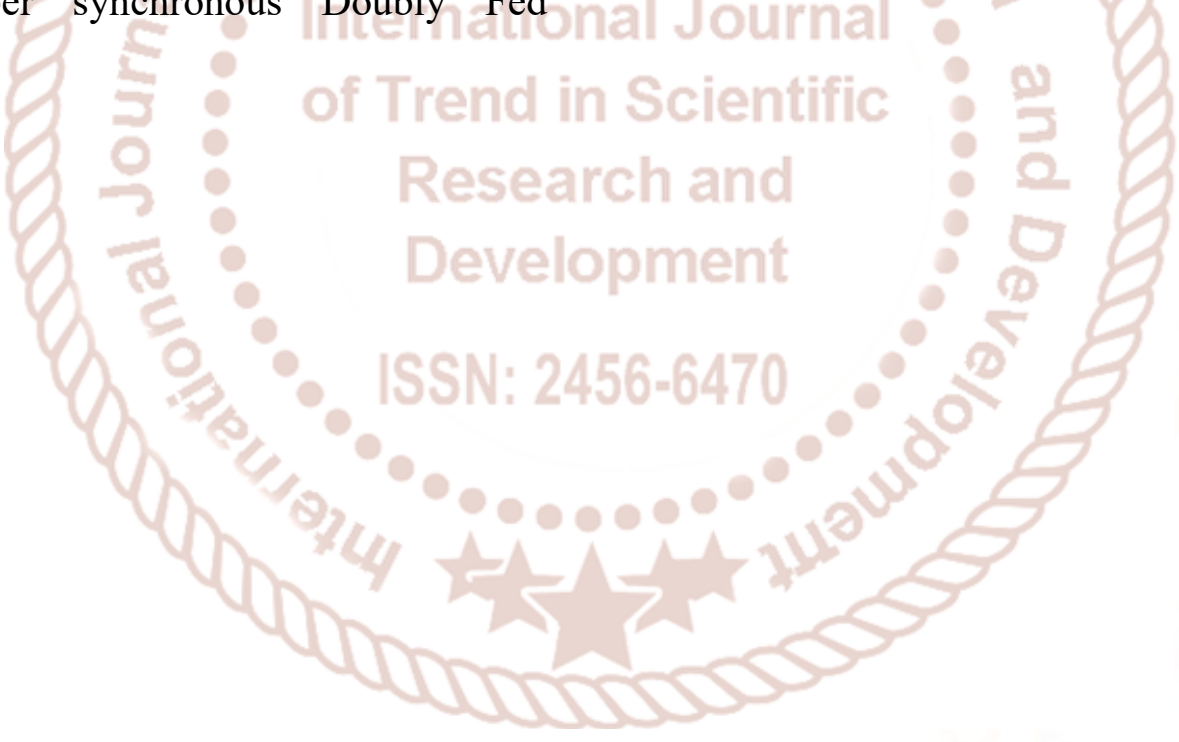

